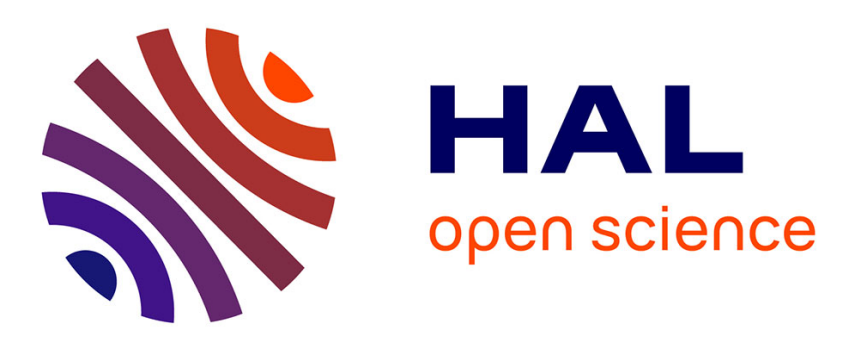

\title{
Ultimate regime of convection: search for a hidden triggering parameter
}

Frédéric Gauthier, Bernard Hébral, Jérémie Muzellier, Philippe-Emmanuel Roche

\section{- To cite this version:}

Frédéric Gauthier, Bernard Hébral, Jérémie Muzellier, Philippe-Emmanuel Roche. Ultimate regime of convection: search for a hidden triggering parameter. 11th EUROMECH European Turbulence Conference, Jun 2007, Porto, Portugal. pp.645-647, 10.1007/978-3-540-72604-3_205 . hal-00198148

\section{HAL Id: hal-00198148 https://hal.science/hal-00198148}

Submitted on 9 Aug 2010

HAL is a multi-disciplinary open access archive for the deposit and dissemination of scientific research documents, whether they are published or not. The documents may come from teaching and research institutions in France or abroad, or from public or private research centers.
L'archive ouverte pluridisciplinaire HAL, est destinée au dépôt et à la diffusion de documents scientifiques de niveau recherche, publiés ou non, émanant des établissements d'enseignement et de recherche français ou étrangers, des laboratoires publics ou privés. 


\title{
Ultimate regime of convection: search for a hidden triggering parameter
}

\author{
F. Gauthier, B. Hébral, J. Muzellier and P.-E. Roche \\ Institut Néel, CNRS et Université J.Fourier \\ BP166, 38042 Grenoble Cedex 9, France
}

\section{Introduction}

In 1962, R. Kraichnan [1] predicted a transition to a new regime of convection for high Rayleigh number, the so called ultimate regime of convection. This regime is characterized by the most efficient thermal transfer of all those predicted in convection. Recently, Rayleigh-Bénard experiments in cryogenics conditions $[2,3,4]$ report apparently contradictory results on the existence of a transition compatible with this regime for Rayleigh numbers above $10^{12}$. Here, we report the first steps of a systematic investigation on the conditions in which the transition can be obtained.

\section{Experimental setup}

The reference cell chosen for comparison with others is the one used by Chavanne et al. [3]: cylindrical cell of aspect ratio 0.5 , cryogenic helium as the working fluid, copper top and bottom plates and a 0.5 mm thick stainless-steel side wall. The Prandtl number is in the region $0.7<\operatorname{Pr}<20$.

The first tested parameter is the conductivity of the plates in order to test the phenomenological model proposed by Chillà and colleagues

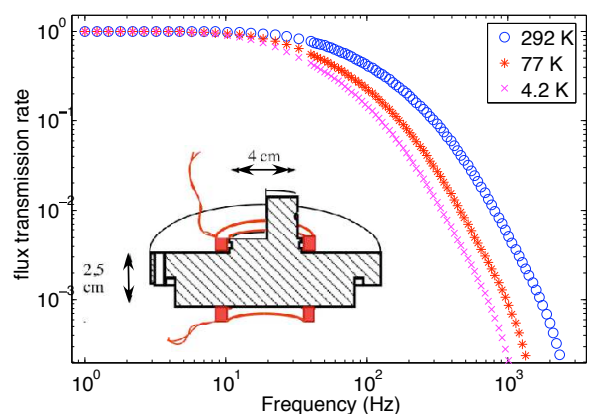

Fig. 1. Magnetic field transfer function through the brass plate.

[5]. The test consists in replacing the bottom copper plate of the Rayleigh Benard cell with a brass plate which has a thermal conductivity about 250 times lower than a copper one. Further details are given in [6]. For reference we present here a method used in the Grenoble's group since 1999 to 
measure the thermal conductivity of plates [this method was suggested to us by L. Puech and P.E Wolf]. We measure the ratio between the electrical conductivity of the plate at room and liquid helium temperature. The thermal conductivity is well-known at room temperature and not very dependent on the impurities and annealing; using Wiedemann-Franz equation $\left(\kappa_{T_{1}} / \sigma_{T_{1}} T_{1}=\kappa_{T_{2}} / \sigma_{T_{2}} T_{2}\right)$ we then calculate the thermal conductivity at liquid helium temperature ( $\kappa$ is the thermal conductivity, $\sigma$ the electrical conductivity and $T$ the temperature). The electrical conductivity measurement is based on a Foucault current approach. Two coils are placed on both sides of the plates (see insert in fig. 1 ). Varying the input voltage frequency of one coil, we measure the currents induced in the other one for different temperatures. It can be shown with Maxwell equations that we can deduce the value of the $\mathrm{RRR}^{1}$ rescaling the frequency on the curves on figure 1 . For the brass plate the $\mathrm{RRR}=\sigma_{4.2 K} / \sigma_{292 K}=2.38$ ( $\mathrm{RRR}=180$ for the copper plate). At $4.2 \mathrm{~K}$ we find a thermal conductivity of $4.0 \mathrm{~W} / \mathrm{m} . \mathrm{K}$ (brass plate) and $1090 \mathrm{~W} / \mathrm{m} . \mathrm{K}$ (copper plate).

A second tested parameter is the influence of the flanges at the interface between plates and the side wall. Indeed the flanges for the Grenoble cells (see fig. 2.) differ from the Oregon one [4] .

Starting from Grenoble flanges design we added a heater ring on the outside of the side wall within $1 \mathrm{~cm}$ above the bottom plate and a temperature regulated copper ring to extract a controled fraction of heat from the side wall within $1 \mathrm{~cm}$ from the top plate. We also put a local heater on the side wall of the cell to try to break the symmetry of

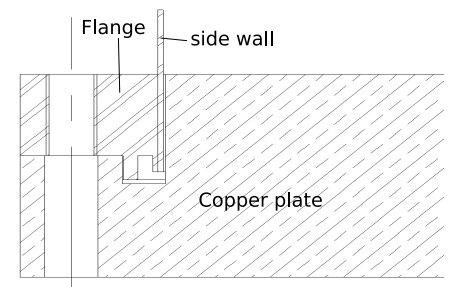

Fig. 2. Detail of the flange assembly for the Grenoble cell.

the flow. The figure 3 sums up a sample of the working conditions $(\mathrm{P}$ is the total power injected into the cell and $Q_{0}$ is the power injected in the top ring in order to compensate the extracted power from the side).

As a third test, we also changed the thickness of the side wall, which was 4 times thicker ( $2 \mathrm{~mm}$ vs $0.5 \mathrm{~mm}$ ) than in the reference cell [7].

\section{Results and concluding remarks}

Data are presented in fig. 4 . We can see that the transition occurence is robust to a strong reduction of the plate conductivity, an axisymetric parasitic heat flux on the side wall near the plate, an axisymetric break by a lateral heat flux on the side wall and a significant thickness increase of the side wall. These parameters in the range of values explored here can't explain the GrenobleOregon controversy.

\footnotetext{
${ }^{1}$ Residual Resistivity Ratio $\left(\sigma_{T_{1}} / \sigma_{T_{2}}\right)$.
} 


\begin{tabular}{|c|c|c|c|c|c|}
\hline serie & 1 & 2 & 3 & 4 & 5 \\
\hline top ring & $Q_{0}$ & $Q_{0}$ & $Q_{0}$ & $0.97 Q_{0}$ & $0.97 Q_{0}$ \\
\hline side heater & 0 & 0 & $0.3 \mathrm{P}$ & 0 & 0 \\
\hline bottom ring & 0 & $0.3 \mathrm{P}$ & 0 & 0 & $0.3 \mathrm{P}$ \\
\hline bottom plate & $\mathrm{P}$ & $0.7 \mathrm{P}$ & $0.7 \mathrm{P}$ & $\mathrm{P}$ & $0.7 \mathrm{P}$ \\
\hline
\end{tabular}

Fig. 3. Different working conditions for the top and bottom ring and the side heater.

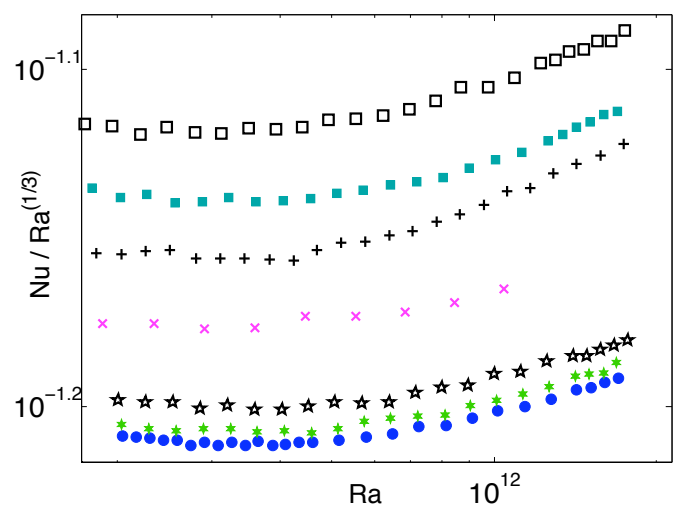

Fig. 4. Compensated Nusselt number $N u / R a^{1 / 3}$ (on a log scale) vs Ra for the brass plate $(+)$, the thick side (x) and for serie 1(full circles), 2(full squares), 3(open squares), 4(full stars), 5(open stars), see figure 3 .

\section{Acknowledgments}

We thank the Région Rhône-Alpes for support.

\section{References}

1. R. Kraichnan: Phys. Fluids 5, 1374 (1962)

2. X. Z. Wu: Along a road to developed turbulence: free thermal convection in low temperature helium gas. Thesis, University of Chicago, Chicago (1991)

3. X. Chavanne et al.: Phys. Rev. Lett.79, 3648 (1997)

4. J.J. Niemela et al.: Nature. 404, 837 (2000)

5. F. Chillà et al.: Phys. Fluids 16, 2452 (2004)

6. P.-E. Roche et al.: Phys. Fluids 17, 115107 (2005)

7. P.-E. Roche et al.: European Physical Journal B 24, 405 (2001) 